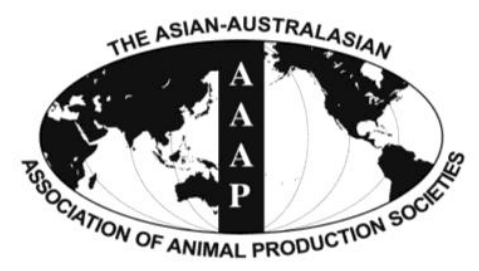

Asian-Aust. J. Anim. Sci.

Vol. 25, No. 6 : 806 - 811

June 2012

www.ajas.info

http://dx.doi.org/10.5713/ajas.2011.11447

\title{
Effects of Plant Extracts on Microbial Population, Methane Emission and Ruminal Fermentation Characteristics in In vitro
}

\author{
E. T. Kim, C. -H. Kim ${ }^{1}$, K. -S. Min ${ }^{2}$ and S. S. Lee* \\ Division of Applied Life Science (BK21 program), Graduate School of Gyeongsang National University, \\ IALS, Jinju, 660-701, Korea
}

\begin{abstract}
This study was conducted to evaluate effects of plant extracts on methanogenesis and rumen microbial diversity in in vitro. Plant extracts (Artemisia princeps var. Orientalis; Wormwood, Allium sativum for. Pekinense; Garlic, Allium cepa; Onion, Zingiber officinale; Ginger, Citrus unshiu; Mandarin orange, Lonicera japonica; Honeysuckle) were obtained from the Plant Extract Bank at Korea Research Institute of Bioscience and Biotechnology. The rumen fluid was collected before morning feeding from a fistulated Holstein cow fed timothy and commercial concentrate (TDN; $73.5 \%$, crude protein; $19 \%$, crude fat; $3 \%$, crude fiber; $12 \%$, crude ash; $10 \%, \mathrm{Ca} ; 0.8 \%, \mathrm{P} ; 1.2 \%$ ) in the ratio of 3 to 2 . The $30 \mathrm{ml}$ of mixture, comprising McDougall buffer and rumen liquor in the ratio of 4 to 1 , was dispensed anaerobically into serum bottles containing $0.3 \mathrm{~g}$ of timothy substrate and plant extracts ( $1 \%$ of total volume, respectively) filled with $\mathrm{O}_{2}$-free $\mathrm{N}_{2}$ gas and capped with a rubber stopper. The serum bottles were held in a shaking incubator at $39^{\circ} \mathrm{C}$ for $24 \mathrm{~h}$. Total gas production in all plant extracts was higher $(\mathrm{p}<0.05)$ than that of the control, and total gas production of ginger extract was highest $(\mathrm{p}<0.05)$. The methane emission was highest $(\mathrm{p}<0.05)$ at control, but lowest $(\mathrm{p}<0.05)$ at garlic extract which was reduced to about $20 \%$ of methane emission ( 40.2 vs $32.5 \mathrm{ml} / \mathrm{g} \mathrm{DM})$. Other plant extracts also resulted in a decrease in methane emissions (wormwood; $8 \%$, onion; 16\%, ginger; $16.7 \%$, mandarin orange; $12 \%$, honeysuckle; $12.2 \%$ ). Total VFAs concentration and $\mathrm{pH}$ were not influenced by the addition of plant extracts. Acetate to propionate ratios from garlic and ginger extracts addition samples were lower ( $\mathrm{p}<0.05,3.36$ and 3.38 vs 3.53 ) than that of the control. Real-time PCR indicted that the ciliate-associated methanogen population in all added plant extracts decreased more than that of the control, while the fibrolytic bacteria population increased. In particular, the F. succinogens community in added wormwood, garlic, mandarin orange and honeysuckle extracts increased more than that of the others. The addition of onion extract increased R. albus diversity, while other extracts did not influence the R. albus community. The $R$. flavefaciens population in added wormwood and garlic extracts decreased, while other extracts increased its abundance compared to the control. In conclusion, the results indicated that the plant extracts used in the experiment could be promising feed additives to decrease methane gas emission from ruminant animals while improving ruminal fermentation. (Key Words: Methane Emission, Microbial Population, Real-time PCR, Relative Quantification Analysis)
\end{abstract}

\section{INTRODUCTION}

Global warming, which results in an increase in the earth's atmospheric temperature, is purported to cause climate change leading to the exacerbation of extreme weather events and the frequency of their occurrence. The increase of greenhouse gases in the atmosphere, in particular methane, has been the focus of a study in global

\footnotetext{
* Corresponding Author: Sung-Sill Lee. Tel: +82-55-772-1883, Fax: +82-55-751-5410, E-mail: 1ss@gnu.ac.kr

${ }^{1}$ School of Animal Life and Environment Science, Hankyong National University, Anseong, 456-749, Korea.

2 Animal Biotechnology, GSBIT, Hankyong National University, Anseong, 456-749, Korea.

Submitted Nov. 24, 2011; Accepted Mar. 2, 2012; Revised Mar. 29, 2012
}

warming (IPPC, 2007), as its contribution is 23 times more potent than carbon dioxide. It was estimated that livestock produced 18\% of all global greenhouse gas emission, greater than all forms of transportation combined. Through their unique digestive process, ruminants emit methane during enteric fermentation and account for approximately $15 \%$ of total methane emission (Takahashi et al., 2005). In addition, methane emission represents a loss of carbon sources from the rumen, leading to an unproductive use of dietary energy, and results in the substantial loss of up to $12 \%$ of the dietary energy intake (Johnson et al., 1995). Various approaches, such as selection of rumen microorganisms through the elimination of protozoa, the inoculation of exogenous bacterial strains and vaccination against methanogenic micro-organisms, have been studied 
with the aim of reducing methane emission of digestive origin. Plant extracts as new feed additives have led to the interest in new, safe and inexpensive ways to reduce methane emission from ruminants. Many plant extracts included tannin and saponin have been studied as possible modifiers of rumen fermentation in order to decrease methanogenesis (Patra et al., 2010). In previous laboratory studies, different plants and additives were extracted with various solvents (methanol, ethanol and boiling water), and the effect on methane emission and ruminal fermentation in in vitro was observed. Patra et al. (2010) suggested that in vitro fermentation might be affected by the dosage of extract as well as the extract solvents. Plants belonging to Compositate and Liliaceae families had a large influence in decreasing methane emission in a previous study.

The objectives of this study were to screen effects of representative plant extracts with known antioxidant properties, as sources of anti-microbial activity for manipulating microbial families within the ruminal ecosystem and to evaluate effects of these plant extracts on methane emission and ruminal fermentation in in vitro.

\section{MATERIALS AND METHODS}

\section{In vitro incubation}

Animal: A fistulated Holstein cow of $500 \mathrm{~kg}$ body weight was used as a donor of rumen fluid. Timothy and commercial concentrate (TDN; $73.5 \%$, crude protein; $19 \%$, crude fat; $3 \%$, crude fiber; $12 \%$, crude ash; $10 \%$, Ca; $0.8 \%$, $\mathrm{P} ; 1.2 \%$, AMINOTEK, CJ feeds) in the ratio of 3 to 2 were fed at $2 \%$ of body weight twice a day. Water and mineralvitamin block were allowed ad libitum.

Rumen fluid: The rumen fluid was collected from the fistulated Holstein cow before morning feeding. Rumen samples were collected in a bottle, previously kept warm and filled with $\mathrm{O}_{2}$ free- $\mathrm{CO}_{2}$ gas, carried to the laboratory, and filtered through four layers of cheesecloth before mixing with buffer maintained at $39^{\circ} \mathrm{C}$ and under $\mathrm{O}_{2}$-free $\mathrm{N}_{2}$ gas.

Plant extracts: Plant extracts were obtained from Plant Extract Bank (PEB) at the Korea Research Institute of Bioscience and Biotechnology. Plants were collected from fields in Korea (Table 1). Each plant was cut into small pieces and dried naturally under shade. Plants were extracted by using methanol $(\mathrm{MeOH})$, and stored at $-20^{\circ} \mathrm{C}$ until use. Stock solution $(20 \mathrm{mg} / \mathrm{ml})$ of the extract was prepared in DMSO (Dimethyl sulfoxide).

In vitro incubation: Rumen liquor was filtered through four layers of cheesecloth before mixing with buffer maintained at $39^{\circ} \mathrm{C}$. The $30 \mathrm{ml}$ of rumen fluid-buffer mixture, comprising McDougall buffer and rumen liquor in the ratio of 4 to 1 , was dispensed anaerobically into serum bottles, filled with $\mathrm{O}_{2}$-free $\mathrm{N}_{2}$ gas, containing $0.3 \mathrm{~g}$ of tomothy substrate and plant extracts (1\% of total volume, respectively), and then capped with a rubber stopper. The serum bottles were held in a shaking incubator (HBS201SL, HANBAEK, Korea) at $39^{\circ} \mathrm{C}$ for $24 \mathrm{~h}$.

\section{Analyses}

Total gas production was measured by the assay of Theodorou et al. (1994). A detachable pressure transducer and a digital readout voltmeter (Laurel Electronics, Inc., CA, USA) were used to measure the headspace gas pressure of fermenting cultures. For the total gas production measurement, the transducer was modified in such a way that it could be linked to the inlet of a disposable Luer-lock three-way stopcock (Theodorou, 1994). Gas pressure in the headspace was read from the display unit after insertion of a hypodermic syringe needle through the butyl rubber stopper above the culture medium. The headspace gas in the serum bottle was collected for analysing the composition of gas, especially methane and carbon dioxide. Methane and carbon dioxide were analysed by the gas chromatography (GC-2010, Shimadzu, Japan) equipped with column (Shincarbon ST. 50/80, Shimadzu, Japan). The incubated inoculum was subsampled for the analysis of $\mathrm{pH}$ (MettleToledo, CH/MP220), volatile fatty acid (VFA) concentration and total DNA extraction. VFA analysis was performed with a gas chromatography (GC-2010, Shimadzu, Japan) as described by Erwin et al. (1961).

\section{DNA extraction, PCR primers and Real-time PCR}

DNA extraction: TissueLyser (Retsch; QIAGEN, Valencia, CA, USA), a high-speed reciprocal shaker which retains samples in screw-capped tubes containing silica beads, was used for DNA extraction. Total nucleic acid was

Table 1. The information regarding plant extracts used in the experiment

\begin{tabular}{|c|c|c|c|c|}
\hline Bar code & & Botanical source & Plant part & Family \\
\hline PB 4921.9 & Wormwood & Artemisia princeps var. orientalis & Whole plant & Compositae \\
\hline PB 2049.1 & Garlic & Allium sativum for. pekinense & Whole plant & Liliaceae \\
\hline PB 2051.1 & Onion & Allium сера & Whole plant & Liliaceae \\
\hline PB 2177.1 & Ginger & Zingiber officinale & Top part & Zingiberaceae \\
\hline PB 3608.1 & Mandarin orange & Citrus unshiu & Leaves, stem & Rutaceae \\
\hline PB 4667.3 & Honeysuckle & Lonicera japonica & Whole plant & Caprifoliaceae \\
\hline
\end{tabular}

Plant extracts were obtained from Plant Extract Bank (PEB) at Korea Research Institute of Bioscience and Biotechnology. 
Table 2. Oligonucleotide primers used for real-time PCR assay

\begin{tabular}{llcc}
\hline Target group & Sequence (5'-3') & $\begin{array}{c}\text { Amplicon } \\
\text { size (bp) }\end{array}$ & Reference \\
\hline General bacteria & CGCCAACGAGCGCAACCC / CCATTGTAGCACGTGTGTAGCC & 130 & Denman et al. (2006) \\
F. succinogens & GGTATGGGATGAGCTTGC / GCCTGCCCCTGAACTATC & 445 & Tajima et al. (2001) \\
R. albus & CCCTAAAAGCAGTCTTAGTTCG / CCTCCTTGCGGTTAGAACA & 175 & Koike et al. (2001) \\
R. flavefaciens & TCTGGAAACGGATGGTA / CCTTTAAGACAGGAGTTTACA & 275 & Koike et al. (2001) \\
Methanogenic archaea & GGTGGTGTMGGATTCACACARTAYGCWACAGC & 440 & Luton et al. (2002) \\
$\begin{array}{l}\text { Ciliate-associated } \\
\text { methanogens }\end{array}$ & / TTCATTGCRTAGTTWGGRTAGTT & & Medlin et al. (1988) \\
\hline
\end{tabular}

extracted from the incubated rumen samples by using the modified bead-beating protocol with the QIAamp DNA mini kit (250) (QIAGEN, USA). For samples, a $1.0 \mathrm{ml}$ aliquot was taken from the $30 \mathrm{ml}$ incubated mixture using a wide bore pipette so as to ensure a homogenous sample containing fluid and digesta. Nucleic acid concentrations were measured by using a NanoDrop Spectrophotometer (ND-1000, USA).

PCR primers: The PCR primer sets used in this study for amplification of general bacteria, Fibrobacter succinogenes, Ruminococcus albus, Ruminococcus flavefaciens, methanogenic archaea and ciliate-associated methanogens were the same as referenced by Denman and McSweeney (2006), Tajima et al. (2001), Koike et al. (2001), Luton at al. (2002) and Medlin et al. (1998), respectively as shown in Table 2 .

Real-time PCR: PCR assays for enumeration of ciliateassociated methanogens and cellulolytic bacterial species were performed according to the methods described by Denman and McSweeney (2006) and Denman et al. (2007) on a Rotor-Gene Real-Time PCR Machine (Crobett life science, Australia) using the iQ SYBR Green Supermix (Bio-Rad Inc., USA). The values of cycle threshold $(\mathrm{Ct})$ after real-time PCR were used to determine fold change (number of fold difference) of different microbial populations relative to the control without extract and plant extracts treatment. Abundance of these microbes were expressed by the equation: relative quantification $=2^{-\Delta \mathrm{CT}}$ (Target)- $\Delta \mathrm{CT}$ (Control), where $\mathrm{Ct}$ represents threshold cycle. All quantative (q) PCR reaction mixtures (final volume of 25 $\mu \mathrm{l})$ contained forward and reverse primers, the iQ SYBR Green Supermix and DNA template ranging from $10 \mathrm{ng}$ to 100 ng. A negative control without the template DNA was used in every qPCR assay for each primer. The PCR amplification of the target DNA, included the annealing and the extension temperature, was conducted following the references in Table 2.

\section{Statistical analysis}

Data were analyzed using the general linear model (GLM) procedure of the Statistical Analysis System Institute, Inc. (SAS, 2002). Differences among means were tested for significance using Duncan's multiple range test of SAS (2002).

\section{RESULTS AND DISCUSSION}

\section{Ruminal fermentation characteristics}

The in vitro total gas production, methane emission and carbon dioxide production are shown in Table 3. Total gas production in all plant extracts was significantly higher $(p<0.05)$ than that of the control, and total gas production from ginger extract was the highest $(p<0.05)$. The methane emission was shown to be the highest $(\mathrm{p}<0.05)$ in control samples, and lowest $(\mathrm{p}<0.05)$ observed in samples containing garlic extract with a reduction of approximately $20 \%$ of methane emission. Other plant extracts also led to a decrease in methane emission. This finding is in agreement with García-González et al. (2008) who reported that bulbs of Allium sativum (garlic) led to a decrease greater than $20 \%$ in both the concentration of methane and in total methane production. Kamra et al. (2008) found that Allium sativum (garlic) extract decreased methane production by more than $25 \%$. Carbon dioxide production in added ginger extract was highest, whereas that of garlic extract was lowest. Total VFAs concentration and $\mathrm{pH}$ were not

Table 3. Effect of plant extracts on total gas, $\mathrm{CH}_{4}$ and $\mathrm{CO}_{2}$ production after $24 \mathrm{~h}$ in vitro incubation

\begin{tabular}{lccrrrrrr}
\hline & Control & Wormwood & Garlic & Onion & Ginger & $\begin{array}{c}\text { Mandarin } \\
\text { orange }\end{array}$ & Honeysuckle & SEM \\
\hline Total gas (ml/g DM) & $210.9^{\mathrm{b}}$ & $228.8^{\mathrm{a}}$ & $228.1^{\mathrm{a}}$ & $229.4^{\mathrm{a}}$ & $230.9^{\mathrm{a}}$ & $226.1^{\mathrm{a}}$ & $223.9^{\mathrm{a}}$ & 1.91 \\
$\mathrm{CH}_{4}(\mathrm{ml} / \mathrm{g} \mathrm{DM})$ & $40.2^{\mathrm{a}}$ & $37.0^{\mathrm{ab}}$ & $32.5^{\mathrm{b}}$ & $33.8^{\mathrm{b}}$ & $33.5^{\mathrm{b}}$ & $35.4^{\mathrm{ab}}$ & $35.3^{\mathrm{ab}}$ & 0.77 \\
$\mathrm{CO}_{2}(\mathrm{ml} / \mathrm{g} \mathrm{DM})$ & $103.9^{\mathrm{b}}$ & $111.1^{\mathrm{ab}}$ & $101.7^{\mathrm{b}}$ & $107.0^{\mathrm{b}}$ & $125.5^{\mathrm{a}}$ & $116.3^{\mathrm{ab}}$ & $114.8^{\mathrm{ab}}$ & 2.38 \\
\hline
\end{tabular}

\footnotetext{
${ }^{\mathrm{a}, \mathrm{b}}$ Means within a row with different superscripts differ significantly $(\mathrm{p}<0.05)$.
} 
Table 4. Effect of plant extracts on ruminal fermentation characteristics after $24 \mathrm{~h}$ in vitro incubation

\begin{tabular}{lcccccccc}
\hline & Control & Wormwood & Garlic & Onion & Ginger & $\begin{array}{c}\text { Mandarin } \\
\text { orange }\end{array}$ & Honeysuckle & SEM \\
\hline $\mathrm{pH}$ & 6.75 & 6.79 & 6.80 & 6.77 & 6.78 & 6.77 & 6.80 & 0.01 \\
Total VFA $(\mathrm{mM})$ & 69.72 & 69.84 & 69.49 & 65.85 & 67.05 & 71.8 & 68.88 & 0.88 \\
Acetate $(\mathrm{mM})$ & 46.18 & 45.74 & 45.27 & 43.12 & 43.55 & 44.81 & 45.11 & 0.43 \\
Propionate $(\mathrm{mM})$ & 13.09 & 13.16 & 13.49 & 12.48 & 12.87 & 13.08 & 13.07 & 0.13 \\
Butyrate $(\mathrm{mM})$ & 7.16 & 7.64 & 7.49 & 7.13 & 7.41 & 7.45 & 7.61 & 0.07 \\
A:P ratio & $3.53^{\mathrm{a}}$ & $3.47^{\mathrm{ab}}$ & $3.36^{\mathrm{c}}$ & $3.45^{\mathrm{abc}}$ & $3.38^{\mathrm{bc}}$ & $3.43^{\mathrm{abc}}$ & $3.45^{\mathrm{abc}}$ & 0.02 \\
\hline
\end{tabular}

$\overline{a, b, c}$ Means within a row with different superscripts differ significantly $(\mathrm{p}<0.05)$.

significantly influenced by the addition of plant extracts. However, total VFAs concentration in added mandarin orange extract was highest while that of onion extract was lowest. The ratio of acetate to propionate in added garlic and ginger extracts was significantly lower $(p<0.05)$ than that of the control (Table 4). Methane emission in the rumen is closely related to the a:p ratio, and the decreased methane emission led to a higher molar proportion of propionate and low a:p ratio (Nellet et al., 1997; Mitsumori et al., 2008). The formation of propionate from succinate would result in a lower availability of $\mathrm{H}_{2}$ for the methanogenesis. It indicated that the antimicrobial properties of these plant extracts might influence methanogenesis, resulting in a reduction in methane emission.

\section{Microbial population in rumen}

Culture-independent molecular techniques were used as tools to obtain information regarding microbial communities without cultivation (Tajima et al., 2001; Denman et al., 2006). Molecular assays, DNA hybridization, real-time PCR, denaturing gradient gel electrophoresis (DGGE) and other techniques have been used to study the quantitative and phylogenetic changes of microbial groups in a ruminal environment. The ciliate-associated methanogen populations were affected by all plant extracts as shown in Figure 1 and were decreased more than that of the control. These findings agreed with other research studies where

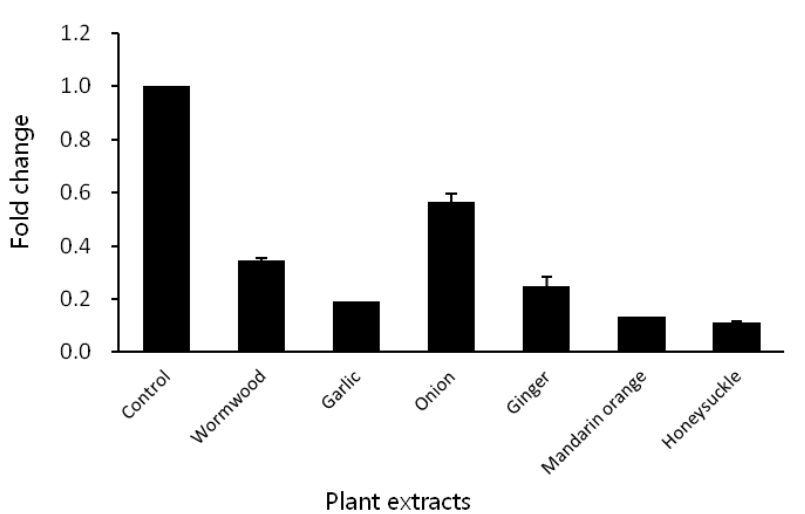

Figure 1. Relative quantification analysis of ciliate-associated methanogen community in vitro ruminal fermentation by the addition of different plant extracts after $24 \mathrm{~h}$ incubation. ciliate-associated methanogen populations were decreased by addition of garlic (Amagase et al., 2001; Patra et al., 2010), ginger (Patra et al., 2006; Sirohi et al., 2009), mandarin orange (Kamra et al., 2008; Tanaka et al., 2010) and honeysuckle extracts (in the present experiment). In the present study, the supplementation of garlic and ginger extracts is speculated to have decreased the protozoa population resulting in reduction of methane emission in the rumen (Table 3) and thus inhibiting methanogenesis (Figure 1). Zhang et al. (2011) reported that the addition of ginger powder affected the ruminal microbial fermentation in an in vivo experiment. Effects of plant extracts on the population of major fibrolytic microorganisms, Fibrobacter succinogens, Ruminococcus albus and Ruminococcus flavefaciens, are shown in Figure 2, Figure 3 and Figure 4, respectively. The $F$. succinogens population in all added plant extracts was shown to have an increasing tendency. In particular, the $F$. succinogens community with the addition of wormwood, garlic, mandarin orange and honeysuckle extracts increased to a greater extent than that of others (Figure 2). The R. albus diversity in added onion extract increased, while other extracts did not influence the $R$. albus community (Figure 3), and the $R$. flavefaciens population decreased with the addition of wormwood and garlic extracts, but compared to the control increased with the addition of other extracts (Figure 4). Fiamegos et al.

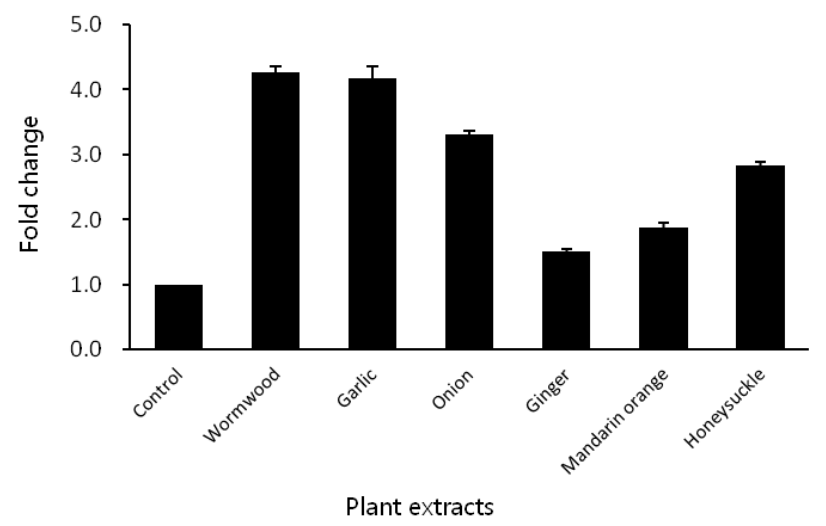

Figure 2. Relative quantification analysis of Fibrobacter succinogens population in vitro ruminal fermentation by the addition of different plant extracts after $24 \mathrm{~h}$ incubation. 


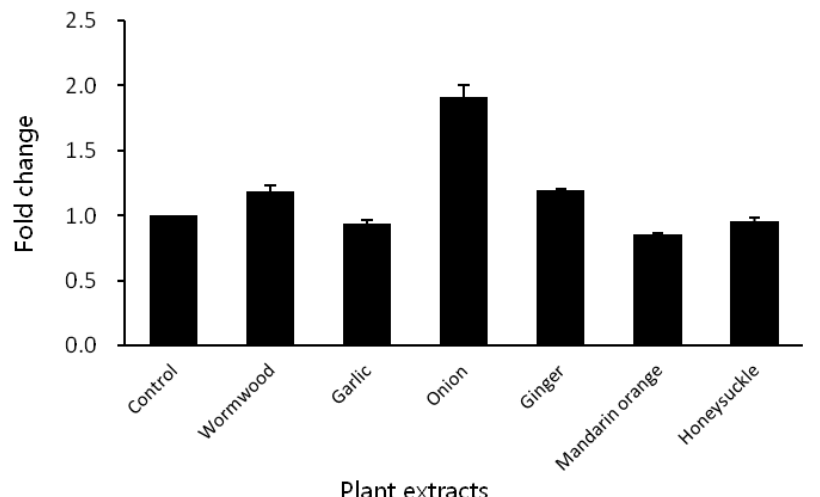

Figure 3. Relative quantification analysis of Ruminococcus albus population in vitro ruminal fermentation by the addition of different plant extracts after $24 \mathrm{~h}$ incubation.

(2011) reported that wormwood (Artemisia absinthium) extracts had a strong antimicrobial activity, particularly against gram-positive pathogenic bacteria. Garlic (Allium sativum) and Onion (Allium cepa) has a wide spectrum of antibacterial activity against gram-negative and grampositive bacteria such as Bacillus subtilis, Salmonella, and E. coli, which has been linked to the presence of a number of small terpenoid and phenolic compounds (Reuter et al., 1996; Wanapat et al., 2008). Muetzel (2003) reported that the growth of $F$. succinogenes and $R$. flavefaciens was not affected by the addition of Sesbania pachycarpa leaves containing saponins to inhibit $R$. albus in vitro. Lonicera japonica (Honeysuckle), which contains a poisonous compound like saponins, toxic alkaloids and tannins, showed similar results against bacteria.

In conclusion, Plant extracts (Artemisia princeps var. Orientalis; Wormwood, Allium sativum for. Pekinense; Garlic, Allium cepa; Onion, Zingiber officinale; Ginger, Citrus unshiu; Mandarin orange, Lonicera japonica; Honeysuckle) were shown to have properties to decrease methanogenesis and may have the potential possibility for use as additives for ruminants without adversely affecting

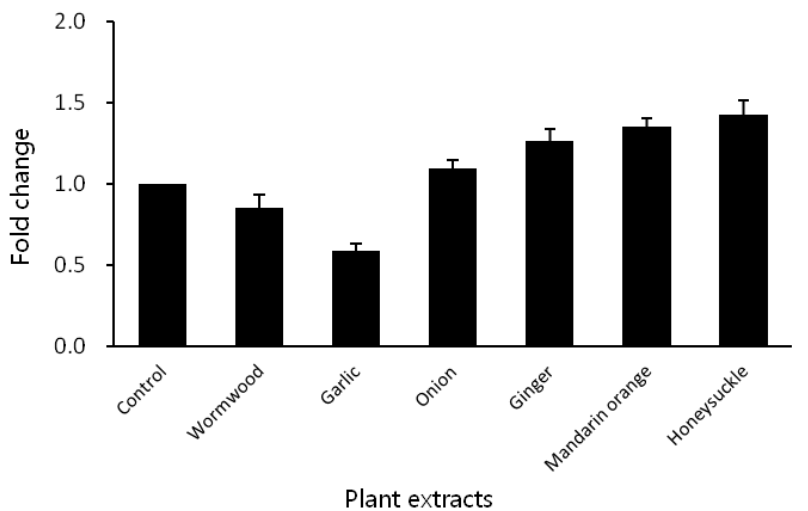

Figure 4. Relative quantification analysis of Ruminococcus flavefaciens population in vitro ruminal fermentation by the addition of different plant extracts after $24 \mathrm{~h}$ incubation. ruminal fermentation. The results indicated that the plant extracts used in the experiment could be promising feed additives to decrease methane emission from ruminants while improving ruminal fermentation.

\section{ACKNOWLEDGEMENTS}

E. T. Kim was supported by a scholarship from the BK21 Program, the Ministry of Education, Science and Technology, Korea.

\section{REFERENCES}

Amagase, H., B. L. Petesch, H. Masuura, S. Kasuga and Y. Itakura. 2001. Intake of garlic its bioactive component. J. Nutr. 131: 9555-9625.

Denman, S. E. and C. S. McSweeney. 2006. Development of a real-time PCR assay for monitoring anaerobic fungal and cellulolytic bacterial populations within the rumen. FEMS Microbiol. Ecol. 58:572-582.

Denman, S. E., N. W. Tomkins and C. S. McSweeney. 2007. Quantitation and diversity analysis of ruminal methanogenic populations in response to the antimethanogenic compound bromochloromethane. FEMS Microbiol. Ecol. 62:313-322.

Erwin, E. S., G. J. Marco and E. M. Emery. 1961. Volatile fatty acid analysis of blood and rumen fluid by gas chromatography. J. Dairy Sci. 44:1768-1771.

Fiamegos, Y. C., P. L. Kastritis, V. Exarchou, H. Han, A. M. J. J. Bonvin, J. Vervoort, K. Lewis, M. R. Hamblin and G. P. Tegos. 2011. Antimicrobial and efflux pump inhibitory activity of caffeoylquinic acids from artemisia absinthium against grampositive pathogenic bacteria. doi:10.1371/journal.pone. 0018127.

García-González, R., S. López, M. Fernández, R. Bodas and J. S. González. 2008. Screening the activity of plants and spices for decreasing ruminal methane production in vitro. Anim. Feed Sci. Technol. 147:36-52.

IPCC (Intergovermental Panel on Climate Change). 2007. IPCC Fourth Assessment Report.

Johnson, K. A. and D. E. Johnson. 1995. Methane emissions from cattle. J. Anim. Sci. 73:2483-2492.

Kamra, D. N., A. K. Patra, P. N. Chatterjee, R. Kumar, N. Agarwal and L. C. Chaudhary. 2008. Effect of plant extracts on methanogenesis and microbial profile of the rumen of buffalo: a brief overview. Aust. J. Exp. Agric. 48:175-178.

Kamra, D. N., N. Agarwal and L. C. Chaudhary. 2006. Inhibition of ruminal methanogenesis by tropical plants containing secondary compounds. Int. Congr. Ser. 1293:156-163.

Koike, S. and Y. Kobayashi. 2001. Development and use of competitive PCR assays for the rumen cellulolytic bacteria: Fibrobacter succinogenes, Ruminococcus albus and Ruminococcus favefaciens. FEMS Microbiol. Lett. 204:361366.

Luton, P. E., J. M. Wayne, R. J. Sharp and P. W. Riley. 2002. The mcrA gene as an alternative to $16 \mathrm{~S}$ rRNA in the phylogenetic analysis of methanogen populations in landfill. Microbiology 148:3521-3530. 
Mitsumori, M. and W. Sun. 2008. Control of rumen microbial fermentation for mitigrating methane emissions from the rumen. Asian-Aust. J. Anim. Sci. 21:144-154.

Medlin, L., H. J. Elwood, S. Stickel and M. L. Sogin. 1988. The characterization of enzymatically amplified eukaryotic 16Slike rRNA-coding regions. Gene 71:491-499.

Muetzel, S. 2003. Supplementation of barley straw with Sesbania pachycarpa leaves in vitro: effects on fermentation variables and rumen microbial concentration structure quantified by ribosomal RNA targeted probes. Br. J. Nutr. 89:445-453.

Nellot, L., D. Demeyer and W. Verstracete. 1997. Effect of 2bromoethanesulfonic acid and Peptostreptococcus productus ATCC 35244 addition on stimulation of reductive acetogenesis in the ruminal ecosystem by selective by inhibition of methanogens. Appl. Environ. Microbiol. 63:194-200.

Patra, A. K., D. N. Kamra and N. Agarwal. 2006. Effect of plant extracts on in vitro methanogenesis, enzyme activities and fermentation of feed in rumen liquor of buffalo. Anim. Feed Sci. Technol. 128:276-291.

Patra, A. K., D. N. Kamra and N. Agarwal. 2006. Effect of spices on rumen fermentation, methanogenesis and protozoa counts in in vitro gas production test. Int. Cong. Ser. 1293:176-179.

Patra, A. K., D. N. Kamra and N. Agarwal. 2010. Effects of extracts of spices on rumen methanogenesis, enzyme activities and fermentation of feeds in vitro. J. Sci. Food Agric. 90:511520 .

Reuter, H. D., J. P. Koch and L. Lawson. 1996. Therapeutic effects and applications of garlic and its preparations. p. 135-212 in Garlic. The Science and Therapeutic Application of Allium sativum L. and Related Species (Ed. H. P. Koch and L. D. Lawsoned). Williams \& Wilkins, Baltimore, MD, USA.

SAS. 2002. SAS user's guide: Statistics (Version 9.01 Ed.). SAS Inst. Inc., Cary, NC, USA.
Sirohi, S. K., N. Pandey, N. Goel, B. Singh, M. Mohini, P. Pandey and P. P. Chaudhry. 2009. Microbial activity and ruminal methanogenesis as affected by plant secondary metabolites in different plant extracts. Int. J. Environ. Sci. Eng. 1:52-58.

Tajima, K., R. I. Aminov, T. Nagamine, H. Matsui, M. Nakamura and Y. Benno. 2001. Diet-dependent shifts in the bacterial population of the rumen revealed with real-time PCR. Appl. Environ. Microbiol. 67:2766-2774.

Tajima, K., T. Nagamine, H. Matsui, M. Nakamura and R. I. Aminov. 2001. Phylogenetic analysis of archaeal 16S rRNA libraries from the rumen suggests the existence of a novel group of archaea not associated with known methanogens. FEMS Microbiol. Lett. 200:67-72.

Takahashi, J., B. Mwenya, B. Santoso, C. Sar, K. Umetsu, T. Kishimoto, K. Nishizaki, K. Kimura and O. Hamamoto. 2005. Mitigation of methane emission and energy recycling in animal agricultural systems. Asian-Aust. J. Anim. Sci. 18:1199-1208.

Tanaka, M., Y. Kamiya, T. Suzuki and Y. Nakai. 2010. Effect of citrus pulp silage feeding on concentration of betacryptoxanthin in plasma and milk of dairy cows. Anim. Sci. J. 81:569-573.

Theodorou, M. K., B. A. Williams, M. S. Dhanoa, A. B. McAllan and J. France. 1994. A simple gas production method using a pressure transducer to determine the fermentation kinetics of ruminant feeds. Anim. Feed Sci. Technol. 48:185-197.

Wanapat, M., P. Khejornsart, P. Pakdee and S. Wanapat. 2008. Effect of supplementation of garlic powder on rumen ecology and digestibility of nutrients in ruminants. J. Sci. Food Agric. 88:2231-2237.

Zhang, T. -T., Z. -B. Yang, W. -R. Yang, S. -Z. Jiang and G. -G. Zhang. 2011. Effects of dose and adaptation time of ginger root (Zingiber officinale) on rumen fermentation. J. Anim. Feed Sci. 20:461-471. 